Agrotekma: Jurnal Agroteknologidan Ilmu Pertanian, 3 (1) Desember 2018

ISSN 2548-7841 (Print); ISSN 2614-011X (Online)

DOI: http://dx.doi.org/10.31289/agr.v3i1.1799

Agrotekma: Jurnal Agroteknologi dan Ilmu Pertanian

Available online http://ojs.uma.ac.id/index.php/agrotekma

\title{
Efektivitas Fungisida Berbahan Aktif Heksakonazol terhadap Penyakit Jamur Akar Putih Bibit Tanaman Karet (Hevea brasiliensis)
}

\section{The Effectiveness of Hexakonazol Fungicide to Prevent of The White Root Disease on Hevea Rubber}

\author{
Mardiana Wahyuni'1), Jenny Hotnida Simanjuntak ${ }^{1)}$ \& Ingrid Ovie Sitompul ${ }^{1)}$
}

1)Sekolah Tinggi Ilmu Perkebunan Medan, Indonesia

Diterima: Agustus 2018; Disetujui: Agustus 2018; Diterbitkan: Desember 2018

*Coresponding Email: mardiana@stipap.ac.id

\begin{abstract}
Abstrak
Penyakit Jamur Akar Putih (JAP) adalah ancaman terbesar perkebunan karet. Serangannya dapat menyebabkan penurunan populasi secara signifikan, terutama pada tanaman berumur 0 - 3 tahun. Patogen yang menyebabkan Jamur akar putih adalah Rigidoporus lignosus. Di daerah endemik JAP, kerapatan pohon menurun dapat mencapai 40-50\%. Pada bibit karet, gejala serangan JAP ditandai dengan perubahan warna pada daun menguning, kemudian mengering dan gugur. Penelitian ini dilakukan di STIP-AP Medan pada Januari 2017 hingga Juni 2017. Tujuan penelitian untuk mengetahui efektivitas beberapa dosis fungisida berbahan aktif heksakonazol. Penelitian ini menggunakan Rancangan Acak Kelompok (RAK) non faktorial dengan empat ulangan. Fungisida heksakonazol aktif dengan perlakuan $A^{0}, A_{1}^{1}, A^{2}, A^{3}$ dan $A^{4}(0,5,10,15$ dan $20 \mathrm{ml} / \mathrm{l}$ air). Hasil penelitian ini menunjukkan bahwa $A^{2}$ aplikasi fungisida aktif-heksakonazol (10 ml / l air) sudah efektif mengendalikan penyakit JAP pada bibit tanaman karet.
\end{abstract}

Kata Kunci: Jamur Akar Putih, Hevea Brasiliensis, Rigidoporus Lignosus, Heksakonazol.

\begin{abstract}
White Root Fungus Disease (JAP) is the biggest threat in rubber. The attack can result in a significant reduction in number, especially in plants lasting 0-3 years. The pathogen that causes white fungus is Rigidoporus lignosus. In JAP endemic areas, decreased tree density 40-50\%. In rubber seedlings, symptoms of JAP attack with yellowing color leaves, then dry and fall. This study was conducted at STIP-AP Medan from January 2017 to June 2017. The aim of the study was to determine the effectiveness of several doses of hexaconazole. This study uses a non-factorial Randomized Block Design (RBD) with four replications. Hexaconazole fungicides are active with treatment of $A 0, A 1, A 2, A 3$ and $A 4$ (0, 5, 10, 15 and $20 \mathrm{ml} / \mathrm{l}$ air). The results of this study indicate that A2 application of hexaconazole-active fungicides (10 ml / l air) has been effective in controlling JAP disease in rubber seedlings.
\end{abstract}

Keywords: Root Disease, Hevea Brasiliensis, Rigidoporus Lignosus, Heksakonazol.

How to Cite: Wahyuni, M. Simanjuntak, J.H. \& Sitompul, I.O. (2018). Efektivitas Fungisida Berbahan Aktif Heksakonazol Terhadap Penyakit Jamur Akar Putih Bibit Tanaman Karet (Hevea brasiliensis). Agrotekma: Jurnal Agroteknologi dan Ilmu Pertanian. 3 (1): 1-9. 


\section{PENDAHULUAN}

Tanaman karet (Hevea brasiliensis Muell Arg) merupakan salah satu komoditas penting perkebunan di Indonesia. Pada tahun 2011, luasnya 3.456 juta hektar. Lebih kurang 84,8\%, merupakan perkebunan rakyat (PR) 6,9\% perkebunan besar nasional (PBN) dan 8.2\% merupakan perkebunan besar swasta (PBS) (Siagian 2015).

Kondisi tanaman yang prima dengan jumlah populasi per hektar yang di dalam budidaya karet penyakit Jamur Akar Putih (JAP) adalah penyakit yang paling merugikan. Menurut Basuki (1986), di perkebunan-perkebunan besar di Sumatera Utara dan Aceh kerugian karena penyakit ini rata-rata $4-7 \%$.

Penyakit JAP pada Tanaman Belum optimal adalah salah satu kunci Patogen yang menyebabkan Jamur Akar mendapatkan produktivitas tanaman yang Putih dikenal dengan beberapa nama yaitu tinggi. Beberapa penyakit penting tanaman Rigidoporus lignosus (Klotzsch Imazeki), karet yang dapat menekan pertumbuhan Rigidoporus micropus (Swartz: Fr van Ov.), tanaman dan menurunkan populasi adalah dan Polyporus lignosus (Klotzsch). Pada penyakit jamur akar putih (JAP), penyakit daerah endemik Jamur Akar Putih, gugur daun sekunder, penyakit jamur penurunan kerapatan pohon dapat upas, dan penyakit cabang Fusarium mencapai 40-50 \%. (Siagian, 2015). Usaha-usaha untuk mencegah telah Kerugian yang ditimbulkan oleh banyak dilakukan, seperti pengolahan serangan penyakit pada tanaman karet lahan mekanis, penanaman kacangan umumnya lebih besar dibandingkan penutup tanah, pemberian serbuk dengan serangan hama. Selain Karen belerang dan penambahan bahan organik; kerusakan akibat serangan penyakit, meskipun demikian usaha ini belum dapat kerugian lain adalah besarnya biaya yang menghilangkan kasus penyakit secara harus dikeluarkan untuk total, sehingga masih diperlukan upaya menanggulanginya. Karenanya upaya pengendalian dengan bahan kimia pencegahan harus mendapat perhatian (Sinulingga dan Basuki, 1991). dan pengamatan dini (EWS) sangat Fungisida "A" (merk) penting. Dengan bahan aktif heksakonazol merupakan fungisida yang efektif Menghasilkan (TBM) merupakan ancaman terbesar perkebunan karet. Serangannya dapat mengakibatkan berkurangnya populasi secara signifikan khususnya pada tanaman berumur 0 - 3 tahun, mengendalikan jamur akar putih (Sinulingga, et al., 1991).

Sehubungan dengan hal tersebut perlu dilaksanakan penelitian tentang efektivitas fungisida berbahan aktif 
heksakonazol terhadap pencegahan penyakit JAP pada pembibitan batang bawah tanaman karet. Selain itu juga menguji efektivitas beberapa dosis fungisida "A" berbahan aktif heksakonazol terhadap pencegahan penyakit JAP di pembibitan batang bawah tanaman karet.

\section{METODE PENELITIAN}

Penelitian telah dilaksanakan di lahan pembibitan STIPER Agrobisnis Perkebunan Medan pada bulan Januari sampai Juni 2017. Penelitian ini menggunakan Rancangan Acak Kelompok (RAK) non faktorial yang terdiri dari 5 perlakuan dan 4 ulangan. Masing-masing perlakuan terdiri dari 3 unit bibit percobaan, sehingga jumlah bibit yang digunakan adalah 60 bibit percobaan.

Perlakuan yang diuji adalah dosis fungisida " $A$ " berbahan aktif heksakonazol:

$\mathrm{A} 1=0 \mathrm{ml} / \mathrm{bibit} / \mathrm{minggu}$

$\mathrm{A} 2=5 \mathrm{ml} / \mathrm{bibit} / \mathrm{minggu}$

$\mathrm{A} 3=10 \mathrm{ml} / \mathrm{bibit} / \mathrm{minggu}$

$\mathrm{A} 4=15 \mathrm{ml} / \mathrm{bibit} /$ minggu .

$\mathrm{A} 5=20 \mathrm{ml} / \mathrm{bibit} /$ minggu

Aplikasi dilakukan selama 6 minggu. Bahan-bahan yang digunakan adalah fungisida " $A$ " dengan bahan aktif Heksakonazol, bibit batang bawah umur 12 bulan, sumber infeksi JAP dari akar pohon karet yang sudah terserang JAP yang diperbanyak pada batang ubi, dan naungan.

Peralatan yang digunakan adalah botol eks infus sebagai alat aplikasi fungisida, gelas ukur, spuit untuk memasukkan larutan fungisida ke dalam botol infus, cangkul, meteran, dan parang Tahapan penelitian meliputi penyediaan lubang tanam, dengan ukuran $25 \times 25 \times 50 \mathrm{~cm}$. Antar blok perlakuan/plot ulangan dibuat jarak $30 \mathrm{~cm}$ untuk menghindari terjadinya kontak akar dari bibit batang bawah dari Pusat Penelitian Karet Sei Putih dengan jenis klon PB 260 umur 12 bulan. Jarak tanam antar bibit yaitu $25 \mathrm{~cm}$ dengan kedalaman tanam 50 $\mathrm{cm}$.

Persiapan inokulum Jamur Ridigoporus lignosus diambil dari akar pohon karet yang terserang JAP dibiakkan pada batang tanaman ubi. Kemudian dibiarkan sampai inokulum jamur R.lignosus tersebut berkembang biak. Lalu diinokulasikan pada bibit batang bawah.

Aplikasi fungisida Heksakonazol menggunakan botol eks infus yang dialirkan ke lubang tanam dengan selang. Pengamatan gejala visual yaitu perubahan fisik pada daun dengan kriteria:

Tingkat 1: Daun muda bila terserang JAP akan menjadi hijau kusam tebal dari daun normal dan ujung-ujung daun mengeriting. Tingkat 2: Daun sudah 
mulai menunjukkan gejala menguning $0=$ Bibit sehat, akar bibit bebas dari tetapi belum merata, masih terlihat daun pathogen.

kusam, lama-kelamaan daun mulai $1=$ Akar bibit telah diinfeksi oleh menguning dan mengering. Tingkat 3: pathogen, tetapi terbatas pada Daun kuning kecoklatan, seluruhnya dan mengering kemudian gugur.

Parameter intensitas serangan jamur 2 = Serangan pathogen sudah membentuk koloni dan meluas dileher akar.

$R$. lignosus dihitung dengan cara 3 = Bagian kulit dan kayu bibit telah membongkar akar bibit dan dilihat miseliumnya.

$$
\mathrm{I}=\frac{\sum(n \times V)}{N \times Z} \times 100 \%
$$
membusuk karena serangan pathogen.
$4=$ Tanaman mati karena serangan pathogen.

Tingkat resistensi/kepekaan

Skala serangan dihitung dengan ditentukan berdasarkan intensitas rumus Townsend dan Heuberger (1943) serangan penyakit dengan kriteria sebagai dalam Unterstenhofer (1976) sebagai berikut (Doni, 2011):

berikut:

$$
\begin{array}{ll}
0 \% & =\text { Sangat resisten } \\
<32 \% & =\text { Resisten } \\
33 \%-67 \% & =\text { Peka } \\
68 \%-100 \% & =\text { Sangat peka. }
\end{array}
$$

$\mathrm{I}=$ Intensitas serangan $\mathrm{n}=$ Jumlah serangan

$\mathrm{V}=$ Nilai dari tiap kategori serangan

\section{HASIL DAN PEMBAHASAN}

$\mathrm{N}=$ Jumlah tanaman yang diamati

Hasil pengamatan gradasi daun $\mathrm{Z}=$ Nilai numeric tertinggi

\begin{tabular}{|c|c|c|c|c|c|c|c|c|c|c|}
\hline Perlakuan & \multicolumn{2}{|c|}{9 MSA } & \multicolumn{2}{|c|}{11 MSA } & \multicolumn{2}{|c|}{13 MSA } & \multicolumn{2}{|c|}{15 MSA } & \multicolumn{2}{|c|}{17 MSA } \\
\hline A0 & \multicolumn{2}{|c|}{10,85} & \multicolumn{2}{|c|}{11,75} & \multicolumn{2}{|c|}{13,15} & \multicolumn{2}{|c|}{14,57} & \multicolumn{2}{|c|}{13,86} \\
\hline A1 & \multicolumn{2}{|c|}{9,40} & \multicolumn{2}{|c|}{11,67} & \multicolumn{2}{|c|}{11,77} & \multicolumn{2}{|c|}{10,32} & \multicolumn{2}{|c|}{11,05} \\
\hline A2 & \multicolumn{2}{|c|}{10,40} & \multicolumn{2}{|c|}{12,57} & \multicolumn{2}{|c|}{12,50} & \multicolumn{2}{|c|}{10,00} & \multicolumn{2}{|c|}{11,25} \\
\hline $\mathbf{A 3}$ & \multicolumn{2}{|c|}{8,75} & \multicolumn{2}{|c|}{10,42} & \multicolumn{2}{|c|}{10,00} & \multicolumn{2}{|c|}{8,15} & \multicolumn{2}{|c|}{9,08} \\
\hline A4 & \multicolumn{2}{|c|}{10,85} & \multicolumn{2}{|c|}{12,72} & \multicolumn{2}{|c|}{13,00} & \multicolumn{2}{|c|}{9,75} & \multicolumn{2}{|c|}{11,38} \\
\hline Rata-rata & \multicolumn{2}{|c|}{10,05} & \multicolumn{2}{|c|}{11,83} & \multicolumn{2}{|c|}{12,08} & \multicolumn{2}{|c|}{10,56} & \multicolumn{2}{|c|}{11,32} \\
\hline$+/-$ & & & \multicolumn{2}{|c|}{1,78} & \multicolumn{2}{|c|}{0,26} & \multicolumn{2}{|c|}{$-1,53$} & 0,7 & \\
\hline Uji F & F hit & F 0,05 & F hit & F 0,05 & F hit & F 0,05 & F hit & F 0,05 & F hit & F 0,05 \\
\hline Perlakuan & 0,10 & 3,26 & 0,09 & 3,26 & 0,16 & 3,26 & 0,59 & 3,26 & 2,24 & 3,26 \\
\hline Blok & 3,16 & 3,49 & 3,33 & 3,49 & 2,79 & 3,49 & 2,04 & 3,49 & 2,12 & 3,49 \\
\hline
\end{tabular}

Nilai kategori serangan sebagai berikut: diawali klosrosis warna, kemudian keriting dan pada kondisi yang lanjut adalah mati/gugur (Tabel 1). 
Jumlah daun yang sakit secara umum mangalami peningkatan dengan rata-rata perbedaan antar pengamatan adalah 0,261,78. Jumlah daun keriting pada awalnya 10,05 dan pada akhir pengamatan 11,32 Uji secara statistik tidak memberikan pengaruh yang nyata. Pada perlakuan A0 terjadi peningkatan pada pengamatan minggu ke-13 ke minggu ke-17. Pada akhir penelitian aplikasi fungisida menurunkan jumlah daun keriting dengan penurunan yang terbaik (angka terendah) yaitu perlakuan A3 (dosis $15 \mathrm{ml}$ ).

Menurut Heru dan Andoko (2008), secara alami daun karet berwarna hijau kemudian menjadi kuning/merah dan akan gugur pada musim kemarau untuk mengurangi penguapan Kontribusi dari fungisida dapat menjaga kesegaran daun, sehinga daun sehat dan dapat melakukan fotosintesa secara maksimal. Hasil pengamatan daun sehat pada Gambar 1.

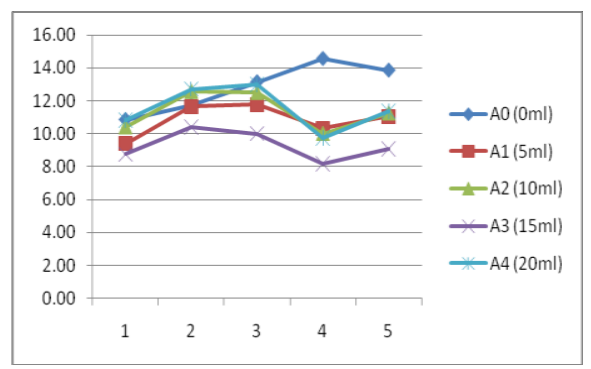

Gambar 1. Grafik Rekapitulasi Daun Keriting Hasil pengamatan daun sehat terdapat pada Tabel 2.

Tabel 2. Rekapitulasi Pengamatan Daun Sehat

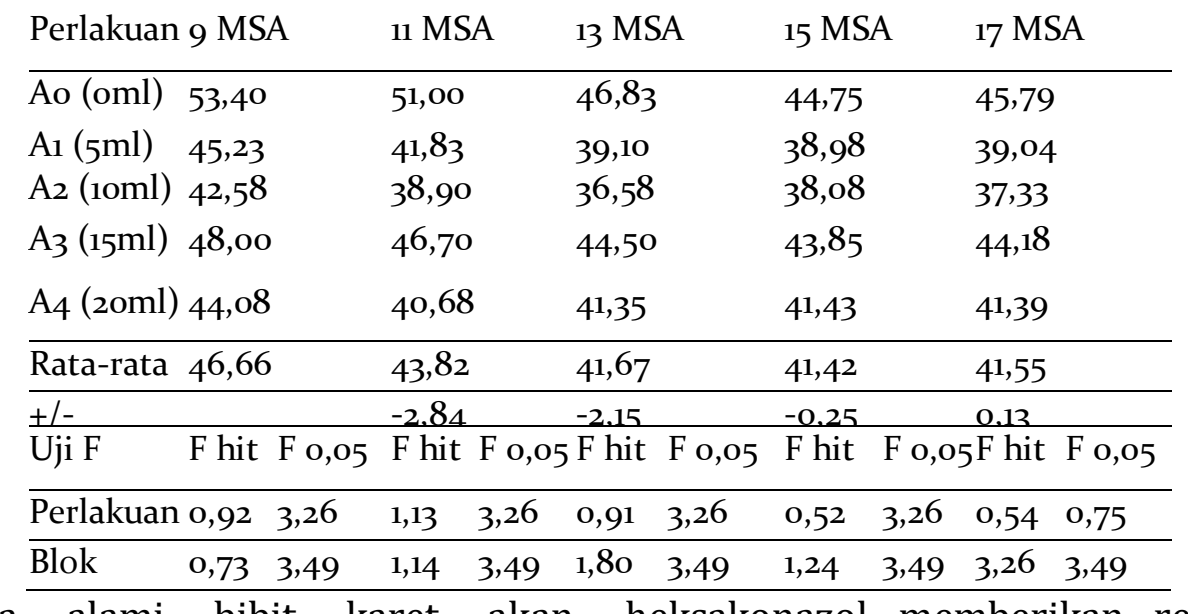

Secara alami bibit karet akan heksakonazol memberikan respon yang mengeluarkan 1 rangkaian daun setiap 2 baik pada A1, A2, A3, dan A4 sehingga minggu, demikian juga secara alami daun tanaman mampu mempertahankan akan kering dan gugur. Jumlah daun sehat kesegaran daun dengan baik. antar waktu pengamatan mengalami Pengamatan infeksi perakaran penurunan yang bervariasi. Pengaruh terdapat pada Tabel 3. perlakuan fungsida dengan bahan aktif 
Tabel 3. Pengamatan Akar

\begin{tabular}{|c|c|c|c|c|c|c|c|}
\hline Perlakuan & $\mathrm{Bib}$ & Sehat & Sakit & Sakit & Sakit & Sakit & Jumlah Sakit \\
\hline$\overline{\text { Ao }}$ & 12 & 7 & 2 & 3 & o & o & \\
\hline Skor & & o & 2 & 6 & o & o & 8 \\
\hline Persentase & & 58,3 & 16,7 & 25,0 & 0,0 & 0,0 & \\
\hline A1 & 12 & 10 & o & 2 & $\mathrm{O}$ & o & \\
\hline Skor & & o & o & 4 & o & o & 4 \\
\hline Persentase & & 83,3 & 0,0 & 16,7 & 0,0 & 0,0 & \\
\hline $\mathrm{A} 2$ & 12 & 12 & o & o & o & o & \\
\hline Skor & & o & o & o & o & o & $\mathrm{O}$ \\
\hline Persentase & & 100,0 & 0,0 & 0,0 & 0,0 & 0,0 & \\
\hline $\mathrm{A}_{3}$ & 12 & 11 & o & 1 & o & o & \\
\hline Skor & & o & o & 2 & o & o & 2 \\
\hline Persentase & & 91,7 & 0,0 & 8,3 & 0,0 & 0,0 & \\
\hline $\mathrm{A}_{4}$ & 12 & 12 & o & o & o & o & \\
\hline Skor & & o & o & o & o & o & o \\
\hline Persentase & & 100.0 & 0,0 & 0,0 & 0,0 & 0,0 & \\
\hline
\end{tabular}

Pada perlakuan A0, jumlah tanaman penyinaran matahari. Spora jamur R. yang sakit adalah 5 bibit (33,3\%). lignosus akan segera berkecambah apabila Dengan waktu 6 bulan, pada perlakuan ini jatuh pada tunggul yang masih segar menunjukkan cukup aktifnya inokulum kemudian miselium menjalar ke perakaran yang diberikan. Benang-benang JAP dalam tanah yang selanjutnya menjadi melekat erat pada perakaran berwarna sumber infeksi.

kuning atau merah kecoklatan (Semangun, Skor perlakuan A0 adalah 8, 1989). intensitas serangan $33,3 \%$ dan termasuk

Kecepatan yang diperlukan dari kategori peka sumber inokulum dipengaruhi oleh beberapa faktor yaitu tekstur tanah, kelembaban, bahan organik dan adanya bahan kontradiktif yang ada pada lingkungan tersebut. Pada kondisi kelembaban yang tinggi maka aktivitas pathogen $R$. lignosus akan cepat membentuk miselium. Miseluim tersebut bergerak ke bawah maupun ke atas/pada leher tanaman atau bibit yang menyebar keluar dikarenakan sifat patogen ini juga responsive terhadap

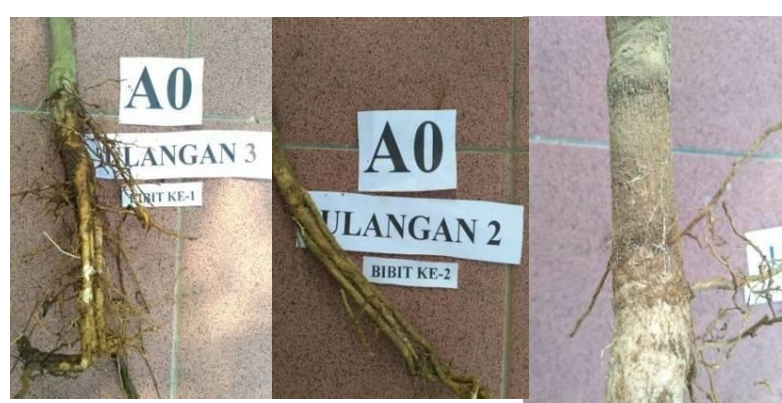

Gambar 2.

a) Akar sehat pada perlakuan Ao

b) Akar kategori sakit 1 yaitu JAP menyerang permukaan kulit

c) Akar kategori sakit 2 yaitu JAP menyerang sampai ke leher akar

Beberapa bahan aktif yang dapat digunakan untuk pengendalian JAP adalah 
Tridemorf, PCNB, Triadimefon, Triadimenol dan Heksakonazol. Heksakonazol yang digunakan dengan formula $50 \mathrm{SC}$, dalam 1 liter terdapat $500 \mathrm{ml}$ bahan aktif merupakan sediaan berbentuk pekatan (konsentrat) cair dengan konsentrasi bahan aktif yang cukup tinggi. Konsentrat cair ini akan membentuk emulsi (butiran benda cair melayang dalam media cair lain) (Djojosumarto, 2008).

Siagian (2015) mengemukakan msalah yang sering dihadapi dalam pengendalian JAP adalah pada saat warna daun berubah menjadi kusam penetrasi JAP sudah luas di jaringan perakaran bahkan saat daun berwarna kuning pengendalian tidak efektif lagi. Basuki (1982) mengemukakan pada kondisi serangan yang parah dapat terbentuk badan buah berbentuk kipas tebal berwarna jingga sampai merah kecoklatan kemudian berangsur warnanya menjadi seram.

Pada perlakuan A1 jumlah bibit yang sehat adalah 10 dan yang sakit adalah 2 dengan skor 4 dan intesitas 16,7\% (resisten). Perlakuan A1 memberikan efek yang sangat baik terhadap penghambatan penularan patogen $R$. lignosus. Sistem aplikasi dengan tetes infus kondisi yang dapat melindungi atau membuat miselium tidak dapat berkembang.

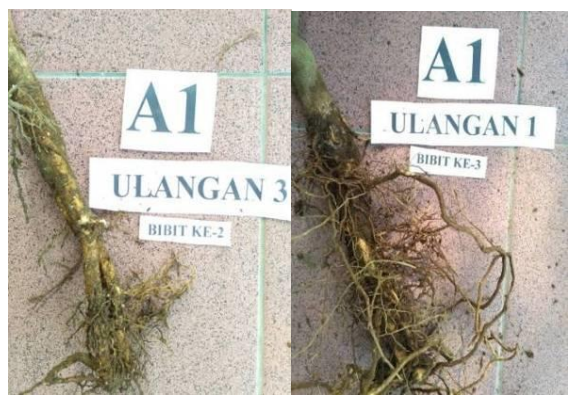

Gambar 3 .

(a) Akar kategori sehat pada perlakuan A

(b) Akar kategori sakit 2, yaitu JAP menyerang sampai ke leher akar

Pada perlakuan A2 seluruh bibit pada kondisi sehat yang dicirikan oleh perakaran segar, tidak ada bagian perakaran yang mengering. Warna kuning segar, menunjukkan aktivitas fisiologi berjalan sangat baik. Dengan adanya penambahan dosis maka aktivitas perkembangan miselium dapat diminimalisir.

Nilai skor maupun intensitas serangan nilainya adalah 0 dan $0 \%$ termasuk pada kategori sangat resisten. Bahan aktif fungisida ini yaitu heksakonazol dengan dosis $10 \mathrm{ml} / \mathrm{l}$ air, dengan frekuensi dan cara aplikasi yang tepat mampu mengendalikan penyakit jamur akar putih dengan baik (Gambar 4).

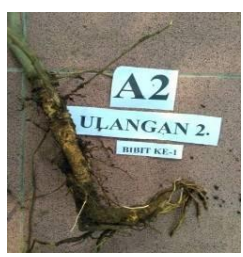

Gambar 4. Visual akar sehat perlakuan A2

Pada perlakuan A3 ini terdapat 1 bibit yang sakit pada kategori sakit 2 
dengan skor, 2 dan intensitas serangan adalah 8,3\% (resisten). Pada prinsipnya tidak banyak perbedaan, ini dapat terjadi oleh adanya variasi yang ada pada lingkungan penelitian. Kondisi perakaran pada perlakuan ini terdapat pada Gambar 5.
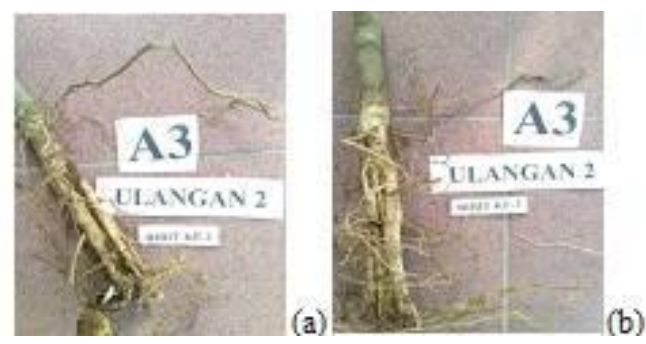

Gambar 5. Visual akar sakit kategori 2, yaitu JAP sudah menyerang sampai ke leher akar.

Pada perlakuan A4 dengan dosis terbanyak yaitu $20 \mathrm{ml} / \mathrm{l}$ air menunjukkan bahwa seluruh bibit sehat, tidak ada yang sakit. Nilai skor 0 dan intensitas $0 \%$ (sangat resisten). Dari data yang diperoleh terdapat kecenderungan bahwa antara pelakuan A2, A3, dan A4 menunjukkan respon yang sama. Dalam menentukan dosis yang diaplikasikan untuk pencegahan dan pengendalian penyakit JAP di pembibitan hal yang lebih penting adalah adanya kontinuitas bahan-bahan desinfektan maupun bahan-bahan yang bersifat kuratif atau membunuh sumber inokulum yang di berikan. Soepana (1993) mengemukakan bahwa intensitas JAP memuncakpada tanaman umur 3-4 tahun saat terjadi pertautan antar akar tanaman di gawangan/baris tanaman.

Hasil skoring dan intensitas pada seluruh perlakuan disajikan pada Tabel 4 .

\begin{tabular}{cccc}
\hline Perlakua & Skor & Intensita & Keterangan \\
\hline A0 & 8 & $33,3 \%$ & Peka \\
A1 & 4 & $16,7 \%$ & Resisten \\
A2 & 0 & $0 \%$ & Sangat Resisten \\
A3 & 2 & $8,3 \%$ & Resisten \\
A4 & 0 & $0 \%$ & Sangat Resisten \\
\hline \multicolumn{2}{c}{ Tabel 4. Intensitas Serangan }
\end{tabular}

Fungisida Heksakonazol merupakan fungisida golongan

triazol (C14H17C12N30), yang berspektrum luas, bersifat kuratif dan protektan untuk mengendalikan jamur patogen. Daya berantas secara sistemik ke seluruh bagian tanaman melalui pembuluh kayu (xylem) (Djojosumarto, 2008).

Mekanisme kerja fungisida golongan triazole tersebut melalui penghambatan biosintesis ergosterol (ergosterolbiosyntesisinhtors). Selain itu fungisida triazole diketahui memiliki daya efikasi dengan spektrum yang luas terhadap cendawan golongan Ascomycetes, Basidiomycetes, dan Deuteromycetes (Sinulingga, et al., 1991).

Perlakuan $\mathrm{A}^{1}, \mathrm{~A}^{2}, \mathrm{~A}^{3}$ dan $\mathrm{A}^{4}$ memperlihatkan hasil resisten sampai dengan sangat resisten.

\section{SIMPULAN}

Perlakuan fungisida " $A$ " dengan bahan aktif heksakonazol menurunkan rata-rata jumlah daun keriting, 
meningkatkan jumlah daun segar dan efektif mempertahankan kesehatan perakaran pada kategori resisten terhadap inoculum JAP, perlakuan $\mathrm{A}^{2}$ sudah cukup efektif.

\section{DAFTAR PUSTAKA}

Basuki. (1982). Penyakit dan Gangguan Pada Tanaman Karet. Pusat Penelitian dan Pengembangan Perkebunan Tanjung Morawa, Medan.

Cahyono, B. (2010). Cara Sukses Berkebun Karet. Pustaka Mina, Jakarta.

Djojosumarto, P. (2008). Panduan Lengkap Pestisida dan Aplikasinya. Halaman 146. Agro Media. Jakarta Pusat.

Heru, D., dan Andoko, A. (2008). Petunjuk Lengkap Budidaya Karet. Agro Media Pustaka. Jakarta.

Nurhakim, I.Y., dan Hani A. (2014). Penyakitpenyakit Penting Tanaman Karet dan Cara Pengendaliannya. Pusat Penelitian Karet.

Semangun, H. (1989). Penyakit - Penyakit Tanaman Perkebunan di Indonesia. Yogyakarta: Fakultas Pertanian Universitas Gadjah Mada.

Siagian, N. (2006). Pembibitan dan Pengadaan Bahan Tanaman Karet Unggul. Pusat
Penelitian Karet, Balai Penelitian Sungei Putih.

Siagian, N. (2015). Cara Modern Mendongkrak Produktivitas Tanaman Karet. Pusat Penelitian Karet, Balai Penelitian Sungei Putih.

Sinulingga, W., dan Basuki. (1991). Efikasi Anvil 50 SC Terhadap Penyakit Jamur Akar Putih (Rigidoporus lignosus) Pada Tanaman Karet. Asosiasi Penelitian dan Pengembangan Perkebunan Indonesia, Pusat Penelitian Perkebunan Sungei Putih.

Sinulingga, W., Basuki dan Soepana, H. (1991). Pemberantasan Jamur Akar Putih Pada Tanaman Karet Dengan Cara Penyiraman Fungisida. Warta Perkaretan 10:1-3. Pusat Penelitian Perkebunan Sungei Putih.

Situmorang, A, dan Budiman, A. (2003). Beberapa Metode Aplikasi Fungisida dalam Pengendalian Penyakit Akar Putih (Rigidoporus lignosus) Pada Tanaman Karet. Prosiding Konfrensi Nasional Karet, Puslitbun Sembawa Buku II. Palembang.

Soepana, H. 1993. Pemberantasan Jamur Akar Putih dengan Trichoderma. Balai Penelitian Sungei Putih: Warta Perkebunan 12 (1).

Sujatno dan Pawirosoemardjo, S. 2001. Pengenalan dan Teknik Pengendalian Penyakit Jamur Akar Putih Pada Tanaman Karet Secara Terpadu. Warta Pusat Penelitian Karet, Vol20 (1-3): 64-75. Balai Penelitian Sungei Putih. 